\title{
Glutathione redox cycle enzymes and selenium in severe rheumatoid arthritis: lack of antioxidative response to selenium supplementation in polymorphonuclear leucocytes
}

\author{
U Tarp, K Stengaard-Pedersen, J C Hansen, E B Thorling
}

\begin{abstract}
The antioxidant capacity of the glutathione redox cycle and the concentrations of selenium in serum, red blood cells or whole blood, and polymorphonuclear leucocytes was evaluated in nine patients with severe rheumatoid arthritis (RA) and eight healthy controls receiving daily supplementation with $250 \mu$ g selenomethionine for six months. Serum and whole blood concentrations of selenium and the activity of the selenium dependent enzyme glutathione peroxidase (GSH-Px) were low in the serum, red blood cells, and polymorphonuclear leucocytes of patients with RA before selenium supplementation. During supplementation serum and whole blood concentrations of selenium and the activity of GSH-Px in serum and red blood cells of patients with $R A$ and serum GSH-Px in controls increased. Selenium and GSH-Px in polymorphonuclear leucocytes were unaffected in patients with RA in contrast with the controls where both were augmented. Glutathione reductase activity in the red blood cells and polymorphonuclear leucocytes of patients with RA was low but increased during selenium supplementation. Whole blood concentrations of glutathione were slightly lower in patients with RA than controls and no difference in the content in polymorphonuclear leucocytes was found between the groups. The activity in red blood cells of glucose-6-phosphate dehydrogenase was high in patients with $R A$, indicating sufficient function of the hexose monophosphate pathway. The reduced antioxidant activity of the glutathione redox cycle in patients with severe RA was mainly due to the low availability of selenium. This was further supported by the response to selenium supplementation in serum and red blood cells. In the polymorphonuclear leucocytes, however, no biochemical effects of selenium supplementation were seen. This lack of antioxidative response could play a pathogenetic part in inflammation in patients with RA.
\end{abstract}

(Ann Rheum Dis 1992; 51: 1044-1049)

Many studies indicate that free oxygen radicals affect the pathogenesis of rheumatoid arthritis (RA) as mediators of inflammation or tissue destruction, or both. ' Several studies have evaluated separate parts of the antioxidative system including parts of the glutathione redox cycle. Glutathione has been shown to be reduced in red blood cells of patients with RA and this is probably related to disease activity. ${ }^{2} 3$ Reports disagree as to whether the levels of the selenium dependent enzyme glutathione peroxidase (GSH-Px) are reduced, ${ }^{4-6}$ normal, ${ }^{7-9}$ or even increased ${ }^{10}$ in RA. The disagreement may originate in the variability of the patients studied. " A low selenium level in the serum and red blood cells of patients with RA has been reported in areas of relatively low and high natural dietary selenium intake. ${ }^{12-16}$ Selenium supplementation within a nutritional range has been shown to increase the concentration of selenium in serum and red blood cells and to stimulate GSH-Px in serum and red blood cells but not in polymorphonuclear leucocytes. ${ }^{4}$

The glutathione redox cycle is part of the defence against the toxicity induced by free oxygen radicals. The cycle comprises glutathione (the tripeptide $\gamma$-glutamylcysteinylglycine) and the enzymes GSH-Px and glutathione reductase (GSSG-R). The system is coupled to the hexose monophosphate pathway by NADP (nicotinamide adenine dinucleotide phosphate), which is used in the glutathione reductase reaction (fig 1). The net result of the cycle reaction is the reductive capacity of GSH-Px, which catabolises hydrogen peroxide and organic peroxides into non-toxic compounds.

The aim of this study was to evaluate the antioxidative capacity of the entire glutathione redox cycle and relate this to the concentrations of selenium in serum, red blood cells, and polymorphonuclear leucocytes before and during six months of supplementation with selenium.

\section{Patients and methods}

PATIENTS AND CONTROLS

The study included nine patients with severe active RA selected on the following criteria:

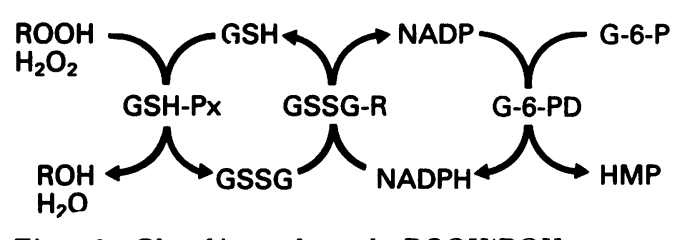

Figure 1 Glutathione redox cycle. $\mathrm{ROOH} / \mathrm{ROH}=$ peroxy radicallalcohol; $\mathrm{H}_{2} \mathrm{O}_{2}=$ hydrogen peroxide;

$G S H-P x=$ glutathione peroxidase; $G S H / G S S G=$ reduced/ oxidised glutathione; $G S S G-R=$ glutathione reductase;

$N A D P H / N A D P=$ reduced/oxidised nicotinamide adenine dinucleotide phosphate; $G-6-P D=$ glucose-6-phosphate dehydrogenase; $G-6-P=$ glucose- $6-$ phosphate; and $H M P=$ hexose monophosphate. 
(a) radiological joint erosions typical of RA; (b) positive reactions for IgM rheumatoid factor; $(c)$ more than seven joints or groups of joints with active arthritis (when assessing the number of joints affected, each group of metacarpophalangeal, proximal interphalangeal, and distal interphalangeal joints of one hand, and also each group of metatarsophalangeal, proximal interphalangeal, and distal interphalangeal joints of one foot were counted as one joint); (d) haemoglobin concentration less than $113 \mathrm{~g} / \mathrm{l}$ for women and less than $129 \mathrm{~g} / \mathrm{l}$ for men; and (e) erythrocyte sedimentation rate (ESR) of more than $40 \mathrm{~mm} /$ hour. The study excluded patients who had been receiving selenium supplements less than three months before the study or who had previously used selenium supplementation other than selenite. Patients with other major diseases and patients receiving systemic corticosteroid treatment were also excluded. The controls consisted of eight healthy subjects not previously supplemented with selenium. In the RA group were eight women and one man. The mean age was $54 \cdot 1$ years (range $24 \cdot 1-72 \cdot 6$ ). The number of joints with active arthritis was nine (range eight to 12). The haemoglobin concentration was 108 g/l (range 100-127) and the ESR $67 \mathrm{~mm} / \mathrm{hour}$ (range 45-93). Four patients were receiving methotrexate, two D-penicillamine, two auranofin, and one sodium aurothiomalate. All also received non-steroidal anti-inflammatory drugs (NSAIDs). In the control group five were women and three men and their mean age was $47 \cdot 2$ years (range $34 \cdot 1-54 \cdot 8$ ). Patients and controls received a supplement of $250 \mu \mathrm{g}$ selenium as L-selenomethionine (Pharma-Nord. Denmark) daily for six months.

\section{ANALYTICAL PROCEDURES}

Blood samples were obtained by venous puncture using dry or heparinised tubes. The samples were drawn two weeks before supplementation, at the start of supplementation, and after three and six months. Preparation of the samples for analysis began immediately after the blood was obtained. Polymorphonuclear leucocytes were isolated from defibrinated blood by sodium metrizoate-Ficoll centrifugation (Lymphoprep, Nyegaard, Oslo, Norway). Contaminating erythrocytes were lysed by water. The final cell suspension contained at least $95 \%$ polymorphonuclear leucocytes. The cells were suspended in $0.175 \mathrm{~mol} / 1 \mathrm{KCl}$.

Samples for glutathione determination were assayed immediately after preparation. After separation into the relevant fractions the samples for determination of GSH-Px, GSSG-R, and glucose-6-phosphate dehydrogenase (G-6-PD) were frozen at $-60^{\circ} \mathrm{C}$. These analyses were carried out within one week of collection. Repetition of assays in red blood cells and serum samples showed that enzymatic activities remained stable for at least four weeks. The samples for the determination of selenium were frozen at $-60^{\circ} \mathrm{C}$ until analysis. All analyses except the particle induced $x$-ray emission (PIXE) analyses were performed in duplicate. Reduced glutathione was determined by the method of Beutler et al. ${ }^{17}$ Fresh whole blood $(0.2 \mathrm{ml})$ or $0.4 \mathrm{ml}$ polymorphonuclear leucocyte homogenate was diluted with $1.8 \mathrm{ml}$ distilled water and mixed with $3 \mathrm{ml}$ of a precipitating solution (1.67 g metaphosphoric acid, $0.2 \mathrm{~g}$ $\operatorname{EDTA}\left(\mathrm{Na}_{2}\right)$, and $30 \mathrm{~g} \mathrm{NaCl}$ in $100 \mathrm{ml}$ water). After filtration $2 \mathrm{ml}$ filtrate, $8 \mathrm{ml} 0.3 \mathrm{~mol} / 1$ $\mathrm{Na}_{2} \mathrm{HPO}_{4}$ and $1 \mathrm{ml}$ 5.5'-dithiobis-(2nitrobenzoic acid) (DTNB) reagent $(40 \mathrm{mg}$ DTNB in $100 \mathrm{ml} 1 \%$ sodium citrate) were mixed and the absorbance was measured at $\mathbf{4 1 2}$ $\mathrm{nm}$. A freshly prepared glutathione solution $0.2 \mathrm{~g}$ in 1 litre water) was used as a standard. Water or $0.175 \mathrm{~mol} / 1 \mathrm{KCl}$ was used in the blank. Concentrations are expressed in $\mathrm{mmol} / \mathrm{l}$ in whole blood and $\mathrm{mmol} / \mathrm{g}$ protein in polymorphonuclear leucocytes. The coefficient of variation $(\mathrm{CV})$ was $7 \%$ in whole blood and $14 \%$ in polymorphonuclear leucocytes.

GSH-Px (E.C. 1.11.1.9) was determined by the modified method of Paglia and Valentine. ${ }^{18}$ The reaction mixture contained 50 $\mathrm{mmol} / \mathrm{l}$ sodium phosphate buffer $(\mathrm{pH} 7 \cdot 4), 1$ $\mathrm{mmol} / \mathrm{l}$ EDTA $\left(\mathrm{Na}_{2}\right), 800$ U/l GSSG-R, 3.75 $\mathrm{mmol} / 1 \mathrm{NaN}_{3}, 5 \mathrm{mmol} / /$ glutathione, $280 \mu \mathrm{mol} / 1$ $\mathrm{NADPH}$, and $45 \mathrm{mmol} / \mathrm{l} t$-butyl hydroperoxide and $50 \mu \mathrm{l}$ haemolysate of red blood cells, undiluted serum or suspension of polymorphonuclear leucocytes. Before the addition of $t$-butyl hydroperoxide the reaction mixture was allowed to incubate (five minutes at $22^{\circ} \mathrm{C}$ ). After the addition of $t$-butyl hydroperoxide the decrease in reduced NADPH was followed at $340 \mathrm{~nm}$. Water or $0.175 \mathrm{~mol} / 1 \mathrm{KCl}$ were used as blanks. The within batch $\mathrm{CV}$ in red blood cells was $6 \%$, in serum $5 \%$, and in polymorphonuclear leucocytes $10 \%$.

GSSG-R (E.C. 1.6.4.2) was determined by the method described by Jensen and Clausen. ${ }^{19}$ The reaction mixture contained $50 \mathrm{mmol} / \mathrm{l}$ sodium phosphate buffer $(\mathrm{pH} 7 \cdot 4), 1 \mathrm{mmol} / \mathrm{l}$ $\operatorname{EDTA}\left(\mathrm{Na}_{2}\right), 280 \mu \mathrm{mol} / \mathrm{l} \mathrm{NADPH}$, and 2.5 $\mathrm{mmol} / \mathrm{l} \mathrm{GSSG}$. The source of enzyme was $10 \mu \mathrm{l}$ haemolysate of red blood cells or $100 \mu$ l homogenate of polymorphonuclear leucocytes. Oxidation of NADPH was measured at $340 \mathrm{~nm}$. The within batch CV in red blood cells was $11 \%$ and in polymorphonuclear leucocytes $13 \%$.

G-6-PD (E.C. 1.1.1.49) was determined by the modified method of Kirkman. ${ }^{20}$ The reaction mixture contained $0.3 \mathrm{~mol} / 1 \mathrm{TRIS} / \mathrm{HCl}$ buffer (pH 8.0), $0.01 \mathrm{~mol} / 1 \mathrm{MgCl}_{2}, 3 \mathrm{mmol} / \mathrm{l} \mathrm{G}$ 6-PD, and $0.2 \mathrm{mmol} / \mathrm{l}$ NADP. The source of enzyme was $20 \mu \mathrm{l}$ haemolysate of red blood cells. The CV in red blood cells was $3 \%$.

To ensure stable analytical conditions internal standards were used in the analysis of GSH-Px, GSSG-R, and G-6-PD in red blood cells. The interassay $C V$ was 11,17 , and $6 \%$ respectively. The enzyme activity was expressed in katals (kat). One katal corresponds to the conversion of one mole of NADP/NADPH per second. The activity in red blood cells is expressed as $\mathrm{mkat} / \mathrm{mol}$ of haemoglobin; in plasma and polymorphonuclear leucocytes as $\mu \mathrm{kat} / \mathrm{g}$ protein.

Concentrations of selenium in plasma and polymorphonuclear leucocytes were determined using the multielement PIXE technique. ${ }^{21}$ Seronorm TM trace elements serum batch No 112 was used as the standard. Selenium in 
Figure 2 Concentrations of selenium and activity of glutathione peroxidase $(G S H-P x)$ in serum of patients with rheumatoid arthritis $(R A)$ and controls during selenium supplementation.
Figure 3 Concentrations of selenium in whole blood and activity of glutathione peroxidase (GSH-Px) in red blood cells of patients with rheumatoid arthritis $(R A)$ and controls during selenium supplementation. whole blood was determined by a fluorometric method as modified by Thorling et al. ${ }^{22}$

\section{STATISTICS}

The results were processed by analysis of variance using the SPSS/PC+ program package. The variables were initially examined graphically to confirm the presence of a normal distribution. The assumption of variance homogeneity was tested by Bartlett's test. A logarithmic transformation was used to stabilise the variances with respect to the selenium concentration data. Multivariate MANOVA (repeated measures) was used to test the effects of time on the biochemical variables among the patients with RA and the control group as well as the time
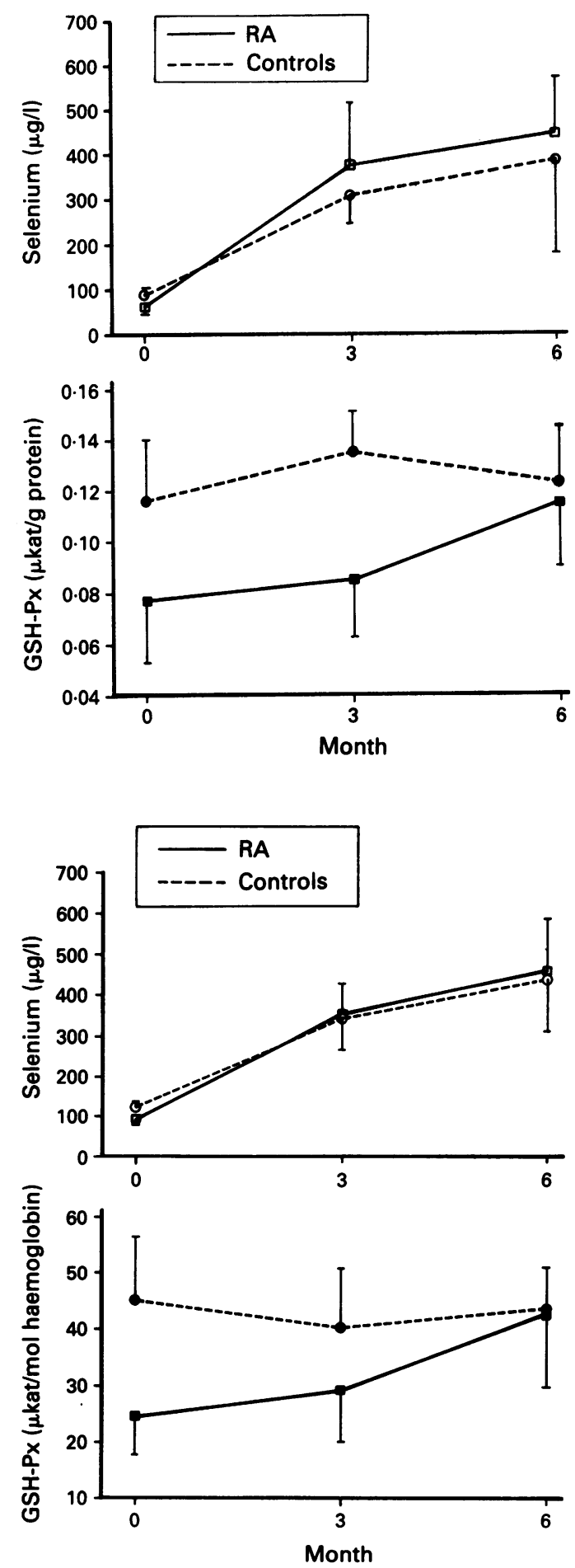

effect in the individual groups. To test differences within the groups a paired sample $t$ test was also used. The difference between the groups at the start of the study was tested by a two sample $t$ test. The level of significance indicated is $\mathbf{5 \%}$. The values obtained at analyses two weeks before supplementation and before the start of the supplementation were calculated as one point.

\section{ETHICS}

The study was approved by the local medical ethics committee of Aarhus county.

\section{Results}

Except for two patients with RA who discontinued supplementation after three months all patients with RA and controls completed the six month supplementation period without any reported side effects.

Selenium concentrations in serum and whole blood were significantly lower in patients with RA than in the controls (mean (SD) serum selenium 61 (17) $\mu \mathrm{g} / 1 \quad v 89$ (12) $\mu \mathrm{g} / 1$; whole blood selenium 95 (14) $\mu \mathrm{g} / \mathrm{l} v 125$ (13) $\mu \mathrm{g} / \mathrm{l}$ ). During supplementation a significant increase was seen, reaching a level that did not vary significantly between the groups (figs 2 and 3 ). No plateau was reached in serum or whole blood samples for the patients with RA, contrary to the controls who reached a plateau after three months. Selenium in polymorphonuclear leucocytes was significantly lower in the patients with RA than in the controls. Betore supplementation no difference was found between the groups. Selenium supplementation did not affect the selenium level in polymorphonuclear leucocytes in the patients with RA but caused a significant increase in the controls (fig 4).
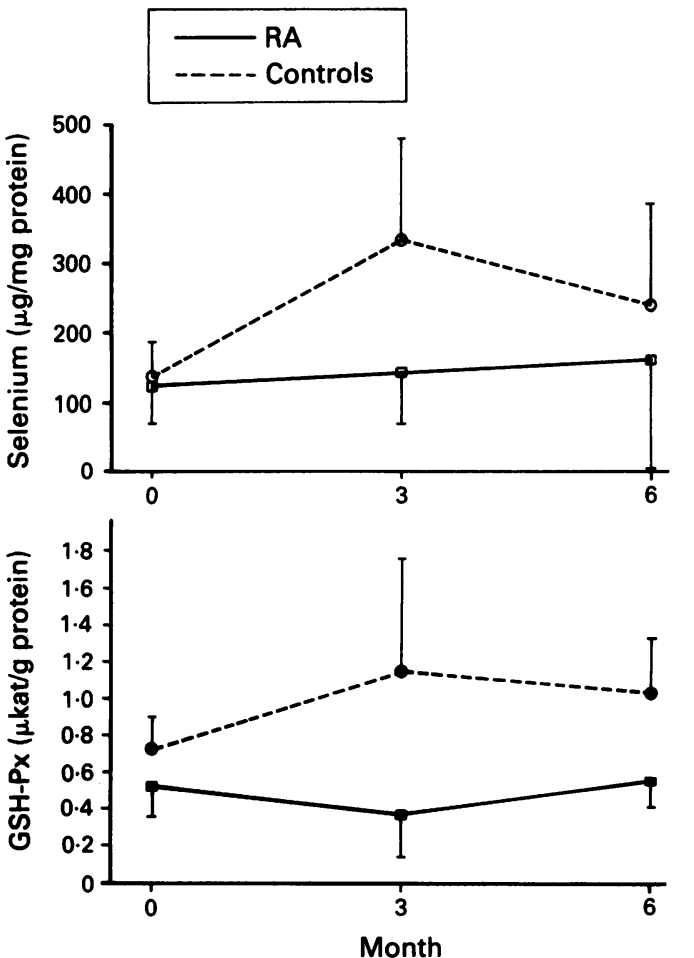

Figure 4 Concentrations of selenium and activity of glutathione peroxidase (GSH-Px) in polymorphonuclear leucocytes of patients with rheumatoid arthritis $(R A)$ and controls during selenium supplementation. 
The patients with RA had a significantly lower serum GSH-Px activity level than the controls before supplementation but the two groups experienced a significant increase during supplementation and after six months no difference was seen (table 1 and fig 2). GSH-Px activity in red blood cells was significantly lower in the patients with RA before supplementation and selenium supplementation increased the activity in patients with RA to a level not different from the controls. In the controls no changes were seen during supplementation (table 1 and fig 3). GSH-Px was significantly lower in the polymorphonuclear leucocytes in the group with RA than in the controls before and during supplementation. No significant change was seen during supplementation in the group with RA whereas a borderline significant increase was seen among the controls (MANOVA, repeated measures; $\mathrm{p}=0.055$ ) (table 1, fig 4).

GSSG-R activity in red blood cells was significantly lower in the patients with RA than in the controls before supplementation. Supple- mentation increased the activity in patients with RA to a level significantly above that of the controls, whereas no changes were seen in the control group (table 2). GSSG-R in polymorphonuclear leucocytes did not differ significantly between the groups although the level tended to be lower in the patients with RA before supplementation and after three months (MANOVA, repeated measures; $\mathrm{p}=0 \cdot 13$ ). During supplementation a significant increase was seen in the rheumatoid arthritis group and the level tended to be higher than that of the controls. No change was seen in the controls during supplementation (table 2).

Glutathione concentrations in whole blood were slightly but not significantly lower in the patients with RA than in the controls (MANOVA, repeated measures; $p=0.07$ ). No significant differences between the groups were recorded before supplementation. Supplementation had no effect in either of the groups (table 3). No significant differences were found among patients with RA and controls with respect to glutathione content in polymor-

Table 1 Glutathione peroxidase (GSH-Px) activity in serum, red blood cells $(R B C)$ and polymorphonuclear leucocytes $(P M N)$ in controls $(C)$ and patients with rheumatoid arthritis $(R A)$ during selenium supplementation

\begin{tabular}{|c|c|c|c|c|}
\hline & Group & Month 0 & Month 3 & Month 6 \\
\hline Serum GSH-Px ( $\mu$ kat/g protein) & $\begin{array}{l}\mathrm{C} \\
\mathrm{RA}\end{array}$ & $\begin{array}{l}0.116(0.024) \\
(0.097-0.136)^{*} \\
0.077(0.024) \\
(0.059-0.096)\end{array}$ & $\begin{array}{l}0.135(0.016) \\
(0.121-0.148) \\
0.085(0.022) \\
(0.068-0.101)\end{array}$ & $\begin{array}{l}0.123(0.022) \\
(0.105-0.142) \\
0.115(0.025) \\
(0.092-0.138)\end{array}$ \\
\hline RBC GSH-Px (mkat/mol haemoglobin) & $\begin{array}{l}\mathrm{C} \\
\mathrm{RA}\end{array}$ & $\begin{array}{l}45 \cdot 2(11 \cdot 2) \\
(35 \cdot 8-54 \cdot 6) \\
24 \cdot 6(6 \cdot 8) \\
(19 \cdot 4-29 \cdot 8)\end{array}$ & $\begin{array}{l}40 \cdot 3(10 \cdot 6) \\
(31 \cdot 4-49 \cdot 2) \\
29 \cdot 2(9 \cdot 1) \\
(22 \cdot 2-36 \cdot 2)\end{array}$ & $\begin{array}{l}43 \cdot 8(7 \cdot 4) \\
(37 \cdot 7-50 \cdot 0) \\
42 \cdot 6(12 \cdot 8) \\
(30 \cdot 8-54 \cdot 4)\end{array}$ \\
\hline PMN GSH-Px ( $\mu$ kat/g protein) & $\begin{array}{l}\mathrm{C} \\
\mathrm{RA}\end{array}$ & $\begin{array}{l}0.72(0.18) \\
(0.57-0.86) \\
0.52(0.16) \\
(0.39-0.64)\end{array}$ & $\begin{array}{l}1.15(0.61) \\
(0.65-1.66) \\
0.37(0.23) \\
(0.19-0.55)\end{array}$ & $\begin{array}{l}1.04(0.30) \\
(0.79-1.28) \\
0.56(0.14) \\
(0.44-0.69)\end{array}$ \\
\hline
\end{tabular}

${ }^{*}$ Results given as mean (SD); $95 \%$ confidence interval for mean in parentheses.

Table 2 Glutathione reductase (GSSG-R) activity in red blood cells (RBC) and polymorphonuclear leucocytes (PMN) in controls $(C)$ and patients with rheumatoid arthritis $(R A)$ during selenium supplementation

\begin{tabular}{|c|c|c|c|c|}
\hline & Group & Month 0 & Month 3 & Month 6 \\
\hline RBC GSSG-R (mkat/mol haemoglobin) & $\begin{array}{l}\mathrm{C} \\
\mathrm{RA}\end{array}$ & $\begin{array}{l}2.57(0.44) \\
(2.20-2.93)^{*} \\
1.62(0.38) \\
(1.32-1.91)\end{array}$ & $\begin{array}{l}1.83(0.65) \\
(1 \cdot 23-2.43) \\
2 \cdot 11(0.97) \\
(1.30-2.92)\end{array}$ & $\begin{array}{l}2 \cdot 24(0 \cdot 88) \\
(1 \cdot 51-2 \cdot 98) \\
2 \cdot 48(0 \cdot 71) \\
(1 \cdot 83-3 \cdot 14)\end{array}$ \\
\hline PMN GSSG-R ( $\mu$ kat/g protein) & $\begin{array}{l}\text { C } \\
\text { RA }\end{array}$ & $\begin{array}{l}0.46(0.14) \\
(0.34-0.57) \\
0.34(0.18) \\
(0.19-0.47)\end{array}$ & $\begin{array}{l}0.39(0.19) \\
(0.23-0.54) \\
0.27(0.15) \\
(0.16-0.39)\end{array}$ & $\begin{array}{l}0.48(0.33) \\
(0.21-0.75) \\
0.56(0.19) \\
(0.39-0.74)\end{array}$ \\
\hline
\end{tabular}

${ }^{*}$ Results given as mean (SD); $95 \%$ confidence interval for mean in parentheses.

Table 3 Glutathione (GSH) concentrations in whole blood and polymorphonuclear leucocytes (PMN) and glucose-6phosphate dehydrogenase $(G-6-P D)$ activity in red blood cells $(R B C)$ of controls $(C)$ and patients with rheumatoid arthritis $(R A)$ during selenium supplementation

\begin{tabular}{|c|c|c|c|c|}
\hline & Group & Month 0 & Month 3 & Month 6 \\
\hline Whole blood GSH (mmol/l) & $\begin{array}{l}\mathrm{C} \\
\mathrm{RA}\end{array}$ & $\begin{array}{l}1.09(0.09) \\
(1.00-1 \cdot 19)^{*} \\
0.97(0 \cdot 16) \\
(0.85-1 \cdot 10)\end{array}$ & $\begin{array}{l}1.01(0.16) \\
(0.88-1 \cdot 14) \\
0.98(0.16) \\
(0.86-1 \cdot 10)\end{array}$ & $\begin{array}{l}1.00(0.16) \\
(0.86-1.13) \\
0.91(0.18) \\
(0.72-1.10)\end{array}$ \\
\hline PMN GSH (mmol/g protein) & $\begin{array}{l}\mathrm{C} \\
\mathrm{RA}\end{array}$ & $\begin{array}{l}0.11(0.08) \\
(0.04-0.18) \\
0.08(0.02) \\
(0.07-0.10)\end{array}$ & $\begin{array}{l}0.14(0.05) \\
(0.09-0.19) \\
0.05(0.04) \\
(0.02-0.09)\end{array}$ & $\begin{array}{l}0.08(0.04) \\
(0.05-0.12) \\
0.07(0.02) \\
(0.05-0.09)\end{array}$ \\
\hline RBC G-6-PD (mkat/mol haemoglobin) & $\begin{array}{l}\mathrm{C} \\
\mathbf{R A}\end{array}$ & $\begin{array}{l}2.20(0.48) \\
(1.75-2.64) \\
2.28(0.45) \\
(1.94-2.62)\end{array}$ & $\begin{array}{l}2.05(0.57) \\
(1.57-2.53) \\
3.02(0.88) \\
(2.29-3.76)\end{array}$ & $\begin{array}{l}1.84(0.63) \\
(1.33-2.36) \\
2.41(0.43) \\
(2.01-2.80)\end{array}$ \\
\hline
\end{tabular}


phonuclear leucocytes and no change in either of the groups was seen during supplementation (table 3).

G-6-PD in red blood cells was significantly higher in the patients with RA throughout the study. No difference between the groups was recorded before supplementation. No change was seen during supplementation in either of the groups (table 3 ).

\section{Discussion}

The patients with RA in this study belong to a subset of patients with RA with persistently high disease activity who had not responded to conventional treatment with disease modifying drugs. The finding of low selenium concentrations in serum and whole blood samples agrees with previous data ${ }^{23}$ and may be interpreted as a response to arthritis activity. ${ }^{14} 15$ Selenium supplementation increased the selenium concentration in the serum and whole blood of patients with RA and controls and no significant differences were observed between the groups at the end of supplementation. Patients with RA had a reduced selenium concentration in polymorphonuclear leucocytes which was unaffected by selenium supplementation. This is in contrast to the increase found in the controls during supplementation and suggests that the selenium metabolism in active $R A$ is affected in the polymorphonuclear leucocytes, probably as a result of the impaired uptake of selenium during the formation of cells in the bone marrow. Previously only one study has dealt with the content of selenium in polymorphonuclear leucocytes in patients with RA. Applying the nuclear microprobe PIXE technique to individual polymorphonuclear leucocytes Lindh and Johansson ${ }^{24}$ could only trace selenium in the polymorphonuclear leucocytes of the controls and not in the three patients with RA studied. Using the same technique selenium supplementation $(200 \mu \mathrm{g}$ selenite/day) was found to increase the content of selenium in polymorphonuclear leucocytes in one healthy subject. ${ }^{25}$

The function of GSH-Px and thereby the net antioxidant capacity of the glutathione redox cycle is dependent on: $(a)$ the available amount of selenium for de novo synthesis of GSH-Px; (b) the intracellular concentration of glutathione; (c) the activity of GSSG-R; and (d) the NADPH generation through hexose monophosphate pathway activity. In this study several components of the glutathione redox cycle were impaired before selenium supplementation.

The G-6-PD activity in red blood cells was significantly higher in the patients with RA than in the controls and no changes occurred during supplementation in either of the groups. The continuously high activity of G-6-PD despite increased GSH-Px/GSSG-R activity suggests that at least in the red blood cell the generation of NADPH is sufficient. In lymphocytes of patients with RA normal production of $\mathrm{NAD}^{+}$ NADH, NADP $(H)$ and ATP has been found. ${ }^{26}$ It may be assumed that similar conditions are found in the polymorphonuclear leucocytes, though we have no data to support it. Thus the low activity of GSH-Px and GSSG-R in red blood cells and polymorphonuclear leucocytes in patients with RA is likely to be explained by either a lack of glutathione or a low selenium level. The glutathione content in red blood cells and polymorphonuclear leucocytes was slightly lower, but no changes were observed when GSH-Px and GSSG-R activities increased. This suggests that the level of glutathione does not limit the glutathione cycle activity. GSSG-R is not a selenium dependent enzyme and the increase in red blood cells and polymorphonuclear leucocytes may be interpreted as a response to increased glutathione cycle activity mediated through GSH-Px. The polymorphonuclear leucocytes of the patients with RA showed a low activity of GSH-Px and the level of GSSG-R also tended to be low. Contrary to the enzyme activity in red blood cells and serum, selenium supplementation did not affect GSH-Px in polymorphonuclear leucocytes in patients with RA whereas an increase was seen in the polymorphonuclear leucocytes of the controls. This is in accordance with our previous findings, ${ }^{4}$ and may be explained by the insufficient increase in selenium in polymorphonuclear leucocytes leading to impaired de novo synthesis of GSH-Px. In the polymorphonuclear leucocytes of the controls a significant increase was found in selenium content and GSH-Px activity, which indicates that the enzyme is unsaturated at the presupplementation level in healthy subjects. In studies of patients developing selenium deficiency during parenteral nutrition the increase in GSH-Px in red blood cells and polymorphonuclear leucocytes has been found to be consistent with the kinetics of production of red blood cells and polymorphonuclear leucocytes. ${ }^{27}$

Several studies have suggested a state of increased oxidative stress and reduced ability to resist attack by radicals in RA. ${ }^{28}$ GSH-Px may be inactivated during oxidative stress ${ }^{29}$ and several experimental studies have indicated that interference with the glutathione peroxidase/ reductase system makes cells more susceptible to oxidative damage. ${ }^{30-32}$

The total antioxidative capacity of the glutathione redox cycle in patients with RA is improved in red blood cells and serum after selenium supplementation but not in the polymorphonuclear leucocytes, which may agree with the lack of clinical response to selenium supplementation in patients with RA. ${ }^{33}$ GSHPx deficient polymorphonuclear leucocytes seem insufficiently protected when exposed to radicals ${ }^{34} 35$ and damage of the polymorphonuclear leucocytes may enhance tissue damage during inflammation. Thus a lack of antioxidative response to selenium supplementation in polymorphonuclear leucocytes could have a pathogenetic role in joint destruction in patients with RA.

Supported by the Danish Rheumatism Association Grant No. 223-493-2.12.88, and Aarhus University Research Foundation Grant No. F-1989-LF-1-56.

1 Greenwald R A. Oxygen radicals, inflammation, and arthritis: pathophysiological considerations and implications for treatment. Semin Arthritis Rhewm 1991; 20: $219-40$.

2 Chilles C, Mulheron M, McCrae F M, Reglinski W E, Sturrock $R$ D. Concentration and reactivity of the sul- 
phydryl group population on the membrane of intact erythrocytes in patients with rheumatoid arthritis. Ann Rheum Dis 1990; 49: 668-71.

3 Munthe E, Kåss E, Jelum E. D-Penicillamine-induced increase in intracellular glutathione correlating to response in rheumatoid arthritis. F Rheumatol 1981; 8 (suppl 7): 14-19.

4 Tarp U, Hansen J C, Overvad K, Thorling E B, Tarp B D Graudal $\mathrm{H}$. Glutathione peroxidase activity in patients with rheumatoid arthritis and in normal subjects: effects of longterm selen.

5 Vanella A, Raqusa N, Campise A, et al. Antioxidant reumato systems in erythrocytes from patients with

6 Munthe E, Jellum E, Aaseth J, Glennås A, T sui E, Bibow K. Thiols, gold salts and selenium in the treatment of rheumatoid arthritis. In: Swaak A J G, Koster J F, eds. Free radicals in arthritic diseases. Rijswijk: Eurage, 1986: 121-8.

7 Borglund M, Åkesson A, Åkesson B. Distribution of selenium and glutathione peroxidase in plasma compared in healthy subjects and rheumatoid arthritis patients. Scand $\mathcal{F}$ Clin Lab Invest 1988; 48: 27-32.

8 Peretz A, Nève J, Vertongen F, Famaey J P, Molle L. Selenium status in relation to clinical variables and corticosteroid treatment in rheumatoid arthritis. $\mathcal{F}$ R heumatol 1987; 14: 1104-7.

9 Sonne $M$, Helleberg $L$, Thode Jensen P. Selenium status in patients with rheumatoid arthritis. Scand $\mathcal{f}$ Rheumatol 1985; 14: 318-9.

10 Braven J, Ansari N, Figgitt D P, et al. A comparison of glutathione reductase and glutathione peroxidase activities in patients with rheumatoid arthritis and healthy adults. $\mathrm{Br}$ in patients with rheumal 1989; 28: 212-5.

11 Tarp U. Selenium glutathione peroxidase in rheumatoid arthritis. $\mathrm{Br} \mathcal{F}$ Rheumatol 1990; 29: 158.

12 Aaseth J, Munthe E, Førre $\emptyset$, Steinnes E. Trace elements in serum and urine of patients with rheumatoid arthritis. Scand I Rheumatol 1978; 7: 237-40.

13 Möttönen T, Hannonen P, Seppälä O, Alfthan G, Oka M. Glutathione and selenium in rheumatoid arthritis. Clin Rheumatol 1984; 3: 195-200.

14 Tarp U, Overvad K, Hansen J C, Thorling E B. Low selenium level in severe rheumatoid arthritis. Scand $\mathcal{f}$ Rheumatol 1985; 14: 97-101.

15 Tarp U, Graudal H, Overvad K, Thorling E B, Hansen J C. Selenium in rheumatoid arthritis. A historical prospective approach. Fournal of Trace Elements and Electrolytes in Health and Disease 1989; 3: 93-5.

16 O'Dell J R, Lemley-Gillespie S, Palmer W R, Weaver A L, Moore G F, Klassen L W. Serum selenium concentrations in rheumatoid arthritis. Ann Rheum Dis 1991; 50: 376-8.

17 Beutler E, Duron O, Kelly B M. Improved method for the determination of blood glutathione. 7 Lab Clin Med 1963; 61: 882-8.

18 Paglia D E, Valentine W N. Studies on the quantitative and qualitative characterization of erythrocyte glutathione peroxidase. f Lab Clin Med 1967; 70: 158-69.
19 Jensen G E, Clausen J. Leucocyte glutathione peroxidase activity and selenium level in Batten's disease. Scand 7 Clin Lab Invest 1983; 43: 187-96.

20 Kirkman H N. Glucose-6-phosphate dehydrogenase and human erythrocytes. Nature 1959; 184: 1291-2.

21 Hertel N. Routine PIXE at the University of Aarhus. Nuclear Instrumentation and Methods 1986; B14: 58-60.

22 Thorling E B, Overvad K, Heerfordt A, Foldspang A. Serum selenium in Danish blood bank donors. Biol Trace Elem Res 1985; 8: 65-73.

23 Peretz A M, Nève I D, Famaey J P P Selenium in rheumatic diseases. Semin Arthritis Rheum 1991; 20: 305-16.

$24 \mathrm{Lindh} U$, Johansson $\mathrm{E}$. The microelement profile in individual blood cells following selenium supplementation and in certain diseases: a nuclear microprobe application. Neurotoxicology 1983; 4: 177-88.

25 Johansson $\mathbf{E}$, Lindh $U$, Landström $E$. The incorporation of selenium and alterations of macro- and trace element levels in individual blood cells following supplementation with sodium selenite and vitamin E. A nuclear microprobe application. Biol Trace Elem Res 1983; 5: 433-47.

26 Chapman M C, Rubin B R, Gracy $R$ W. The redox state in lymphocytes from patients with rheumatoid arthritis. F Rheumatol 1986; 13: 850-2.

27 Cohen $H$ J, Brown M R, Hamilton D, Lyons-Patterson J, Avissar N, Liegey P. Glutathione peroxidase and selenium deficiency in patients receiving home parenteral nutrition: time course for development of deficiency and repletion of enzyme activity in plasma and blood cells. Am $\mathcal{F}$ Clin Nutr 1989; 49: 132-9.

28 Situnayake R D, Thurnham D F, Kootathep S, et al. Chain breaking antioxidant status in rheumatoid arthritis: clinical and laboratory correlates. Ann Rheum Dis 1991; 50: 81-6.

29 Condell R A, Tappel A L. Evidence for suitability of glutathione peroxidase as protective enzyme: studies of oxidative damage, renaturation and proteolysis. Arch Biochem Biophys 1983; 223: 407-16.

30 Baker M S, Feigan J, Lowther D A. Chondrocyte antioxidant defences: the roles of catalase and glutathione peroxidase in protection against $\mathrm{H}_{2} \mathrm{O}_{2}$ dependent inhibition of proteoglycan biosynthesis. F R hewmatol 1988; 15: 670-7.

31 Nathan C F, Arrick B A, Murray H W, DeSantis N M, Cohn $\mathrm{Z} A$. Tumour cell anti-oxidant defenses. Inhibition of the glutathione redox cycle enhances macrophage-mediated cytolysis. F Exp Med 1980; 153: 766-82.

32 Suttorp N, Simon L M. Importance of the glutathione redox cycle for the resistance of lung epithelial cells against a polymorphonuclear leucocyte-mediated oxidant attack. Biochem Pharmacol 1986; 35: 2268-70.

33 Tarp U, Overvad K, Thorling E B, Graudal H, Hansen J C. Selenium treatment in rheumatoid arthritis. Scand $\dot{f}$ Rheumatol 1985; 14: 364-8.

34 Baker S S, Cohen $\mathbf{H}$ J. Altered oxidative metabolism in selenium-deficient rat granulocytes. F Immunol 1983; 130: 2856-60.

35 Salin M L, McCord J M. Free radicals and inflammation. Protection of phagocytosing leukocytes by superoxide dismutase. $\mathcal{f}$ Clin Invest 1975; 56: 1319-23. 